\title{
TRANSITION TO A CIRCULAR ECONOMY MODEL IN THE EUROPEAN UNION - STATE AND OUTLOOK
}

\author{
Vania Ivanova ${ }^{1^{*}}$, Sonia Chipeva ${ }^{2}$ \\ ${ }^{1}$ Ass. Prof.Dr., Department of Economics, University of National and World Economy, Bulgaria. E- \\ mail: arbneda@abv.bg \\ ${ }^{2}$ Ass. Prof.Dr., Department of Statistics and Econometrics, University of National and World \\ Economy, Bulgaria. E-mail: sonia.chipeva@hotmail.com \\ ${ }^{*}$ Corresponding author
}

\begin{abstract}
The transition towards a circular economy requires fundamental changes to production and consumption systems, going well beyond resource efficiency and recycling waste.Circular economy is a closed cycle covering each of the three areas: the supply and responsible choice of the producers, the demand and the consumer behaviour and the waste management. It is a model aiming at preserving and increasing the value of resources used in production and consumption, while reducing their impact on the environment, during the whole life cycle of the products. Circular economy has as its immediate objective an optimal management of all resources (material resources, energy sources, water and land use being the main issues). The objectives are to be pursued: create new opportunities for growth and economic performance while reducing resource use, boost the competitiveness and limit the environmental impacts of resource use.This change was recognized in Europe, with the European Commission's Communication "Roadmap to a Resource Efficient Europe", published in January 2011(COM(2011) 571). In the following years, many European Union and national public policies and programmes were designed and introduced in order to keep abreast of the profound changes the model of circular economy and society brings into our world. In order to successfully meet the EU's resource efficiency targets by 2030 , the transition to a circular economy model should become a state priority.
\end{abstract}

The aim of this paper is to draw out the differences and similarities between the EU countries regarding the transition to a circular economy model and to assess progress on this basis.

Quantitative and qualitative research methods were employed for data collection and analysis: database research and analysis, descriptive statistics, cluster analysis.

The survey results indicate the presence of too much heterogeneity among EU countries in the transition to a circular economy. This suggests that, in parallel with private sector initiatives, public authorities should coordinate, support and promote environmental, economic and social changes leading to accelerate this transition.

Keywords: circular economy, sustainable development, resource productivity, waste management, cluster analysis

\section{INTRODUCTION}

The EU efforts towards a sustainable, low-carbon, competitive and resource-efficient economy are closely linked to the circular economy concept. On December 2015, the Commission adopted a Circular Economy 
package consisting of a Communication and an action plan and proposals for revised legislation on waste ${ }^{1}$. It indicated that 'the transition to a more circular economy, where the value of products, materials and resources is maintained in the economy for as long as possible, and the generation of waste minimised.' Circular economy is a model aiming at preserving and increasing the value of resources used in production and consumption, while reducing their impact on the environment, during the whole life cycle of the products.

Making such a transition provides an opportunity for greening the economy and creating new competitive advantages. Therefore the actions in the field of circular economy are directly linked to EU's major priorities, including jobs and growth, investments, climate and energy programme, industrial innovations and the renewed EU Industrial Policy Strategy ${ }^{3}$. At the same time, realisation of this strategy will contribute to achieving the 2030 Sustainable Developent Goals(SDGs), in particular SDG 12 towards responsible patterns of consumption and production.

The traditional model must therefore be replaced with a circular economy model aiming at closing the loop of resources and reducing the environmental impact of the product life cycle at all stages of the process (production, distribution, consumption).

Unlike the linear economy model (extraction, production, consumption and waste), circular economy produces goods and services while limiting the use of raw materials and energy and reducing waste generation. To respond to the contemporary challenges for the economy in the face of the scarce and finite, and increasingly costly resources, on the one hand, and the environmental needs, on the other, circular economy steps on three underlying principles: creating and developing natural capital, optimising resource consumption and creating 'closed systems' with minimum negative externalities. The actions support the circular economy in each step of the value chain - from production to consumption, repair and remanufacturing, waste management, and secondary raw materials that are fed back into the economy.

This is a practice-oriented concept. Central in this model is the production of products intended for long-term use at a maximum resource efficiency. They have to be produced in a way that allows for repair, plus ensuring the maintenance of spare parts production. Products must be suited for reuse or shared use, and should have maximum life span. And just as importantly, circular economy implies the creation of products that are made to decompose and their components or subsystems are reusable as components in making new products. Recycling (as far as is possible) of the parts that cannot be reused or repaired is crucial.

Waste management is at the core of circular economy: it is essential for the practical implementation of the EU waste hierarchy. The Circular Economy Action Plan (2015) includes revised proposals on waste legislation and a comprehensive action plan which sets out concrete actions. The Circular Economy Action Plan and its waste legislation should be fully implemented to minimise waste, to separately collect, reuse and transform bio-waste as well as by-products and residues into high-added-value compounds.

Waste management proposals contain a clear and ambitious long-term vision on increasing recycling and reducing landfilling of waste. There are clear links between the Circular Economy Action Plan and the Circular Economy Policy Package(2018). Targets and ambitions formulated in the EU Circular Economy Package which offers great opportunities to make better and more efficient use of resource and to reduce overall resource consumption. According to Ellen MacArthur Foundation data, in 2014, annually in EU 8 billion tonnes of materials were processed into energy or products. Only 0,6 billion tonnes came from recycling. Of the 2,2 billion tonnes of generated waste, merely 0,6 billion tonnes went back to the system as recycled materials. The rest of the materials, amounting to some 1,5 billion tonnes, were waste. These aspects suggest there is a considerable room for improvement, more specifically by increasing the share of materials recycled to secondary raw materials and by reducing waste generation.

Circular economy relates to the ability of an economy to grow while reducing the use of resources. The shift to a circular economy aims to achieve 'dematerialisation' - i.e., an absolute and relative reduction of the amount of materials utilsed, as well as of the amount of waste. The circular economy concept, however, goes a step further. The products in a circular economy are not only not wasted, but are also created in a way that allows them to be easily repaired, converted into or combined with other products. Businesses have a responsibility for their products far beyond their selling point, with the key principle being cooperation among the various industries so that each one of them could use waste materials from the others.

Circular economy provides the key points of reference as to what must be done in order to reduce substantially and lastingly economy's reliance on resources, and move towards overcoming the scarecity of

\footnotetext{
${ }^{1} \operatorname{COM}(2015)$ 593, $\operatorname{COM}(2015)$ 594, $\operatorname{COM}(2015) 595$ and $\operatorname{COM}(2015) 596$

${ }^{2} \operatorname{COM}(2015) 614$

${ }^{3} \operatorname{COM}(2017) 479$.
} 
non-renewable natural resources. It is a new way of interpreting the existing links between markets and economic operators and rethinking the perception of waste as natural resource.(Ivanova, 2013). Circular economy has as its immediate objective an optimal management of all resources (material resources, energy sources, water and land use being the main issues). The objectives are to be pursued: create new opportunities for growth and economic performance while reducing resource use, boost the competitiveness and limit the environmental impacts of resource use.

A transition such as this cannot happen instantly, effortlessly and automatically. The EU countries have different traditions and implement varied policies supportive of ecological transition. They also have widely differing production structures, which need different time to adjust.

In the transition to circular economy, monitoring of the key trends and patterns is a basic tool for understanding the way in which the various elements of circular economy develop over time, identifying the success factors in the Member States, and forming judgements about the adequacy of measures undertaken. The results from such monitoring should serve as the basis for setting new priorities leading towards the long-term objective of circular economy.

\section{METHODOLOGY}

The aim of this paper is to draw out the differences and similarities between the EU countries regarding the transition to a circular economy model and to assess progress on this basis.

The methodology adopted by Eurostat for monitoring the progress of transition to a circular economy model identifies four groups of indicators. These encompass a set of ten key indicators which cover each phase, i.e., production, consumption, waste management and secondary raw materials, as well as economic aspects - investments and jobs, and innovation.

To fulfil the purpose of this study, it is important to capture fully many aspects of circular economy. Therefore, to form the clusters and analyse the status and progress of the countries within each cluster, a total of 8 out of the 10 indicators were selected. The resource productivity and domestic material consumption(DMC) indicator was added, being a part of the indicators monitored under Goal 12 (Responsible production and consumption) from the SDGs, as it gives an indication of resource efficiency, which is one of the immediate tasks under a circular economy.

The selection of indicators is made in accordance with the principles and goals of circular economy, on the one hand, and the framework of indicators adopted by the European Commission, on the other. Since waste management and recovery is crucial, four out of the 9 selected indicators are linked to the total share of waste and the part that is recycled.

The analysis is made based on:

* Generation of waste excluding major mineral wastes per GDP unit (cei_pc032)

* Generation of waste excluding major mineral wastes per domestic material consumption (cei_pc033)

* Recycling rate of municipal waste (cei_wm011)

* Recycling rate of all waste excluding major mineral waste (cei_wm010)

* Circular material use rate (cei_srm030)

* Gross Value Added (cei_cie010)

* Private investments (cei_cie010)

- Jobs (cei_cie010)

* Resource productivity and domestic material consumption (DMC)

The indicators were chosen by taking into account the available data, building on the resource-efficiency index. Other indicator assessment criteria included relevance, acceptability, reliability, simplicity of use, and sustainability. The data for the specified indicators are taken from Eurostat in its capacity as the EU's single statistical structure. The data used are for 2014 and 2016, which is the last year with aggregated data at EU level and by individual Member State, and the analysis is made successively for 2014 and 2016.

Cluster analysis is conducted using data for 2014 nad 2016. The purpose is to determine whether any changes have occurred in the existing EU models after the adoption of the Circular Economy package and whether the countries are moving closer to one another in the transition to circular economy. This allows to determine whether a particular group of countries stand out as experiencing more tangible transformation 
towards circular economy and where things are seriously lagging behind.

Within the cluster analysis the differentiating ability of the used criteria has been tested using F-test (Fisher's test). It has served for exploring if the selected criteria could be regarded as structural determinants for the formation of models within the EU.

\section{RESULTS AND DISCUSSION}

The results shown in Table 1 lead to the conclusion that four of the selected criteria could be regarded as structural determinants at $5 \%$ significance level. Based on them 3 groups of countries with similar characteristics are formed.

Table 1. Differentiating power of the criteria according to the F-test

\begin{tabular}{|c|c|c|c|c|c|c|}
\hline & \multicolumn{2}{|c|}{ Cluster } & \multicolumn{2}{|l|}{ Error } & \multirow[t]{2}{*}{$\mathrm{F}$} & \multirow[t]{2}{*}{ Sig. } \\
\hline & Mean Square & df & Mean Square & df & & \\
\hline $\begin{array}{l}\text { All waste generated per } \\
\text { GDP unit } 2016 \\
\text { (kg/thousand euro) }^{1}\end{array}$ & 206769,756 & 2 & 1910,447 & 25 & 108,231 & ,000 \\
\hline $\begin{array}{l}\text { All waste generated per } \\
\text { DMC unit } 2016(\% \text { of } \\
\text { DMC) }\end{array}$ & 156,721 & 2 & 55,018 & 25 & 2,849 & ,077 \\
\hline $\begin{array}{l}\text { Recycling rate of } \\
\text { municipal waste } 2016 \text { (\% } \\
\text { ot total municipality } \\
\text { waste) }\end{array}$ & 463,699 & 2 & 198,611 & 25 & 2,335 & , 118 \\
\hline $\begin{array}{l}\text { All recycling waste } 2016 \\
(\% \text { of total waste })^{3}\end{array}$ & 1152,929 & 2 & 226,124 & 25 & 5,099 &, 014 \\
\hline $\begin{array}{l}\text { Circular material use rate } \\
2016 \text { ( } \% \text { of total material } \\
\text { use) }\end{array}$ & 64,254 & 2 & 41,624 & 25 & 1,544 & ,233 \\
\hline $\begin{array}{l}\text { Gross value added } 2016 \\
(\% \text { of GDP) }\end{array}$ & , 134 & 2 & ,152 & 25 & ,887 & ,425 \\
\hline $\begin{array}{l}\text { Private investment } 2016 \\
(\% \text { of GDP })^{2}\end{array}$ & ,033 & 2 & ,003 & 25 & 10,741 &, 000 \\
\hline $\begin{array}{l}\text { Jobs } 2016 \text { ( } \% \text { of total } \\
\text { employed) }\end{array}$ & 1,259 & 2 & ,611 & 25 & 2,062 & , 148 \\
\hline $\begin{array}{l}\text { Resource productivity } \\
\text { and DMC } 2016 \text { indexes } \\
\text { to } 2000=100 \%{ }^{4}\end{array}$ & 5173,577 & 2 & 1062,204 & 25 & 4,871 & , 016 \\
\hline
\end{tabular}

Source: author's calculations obtained using a cluster analysis in SPSS

* The numbers of the indicators show the sequence of their differentiating power as ${ }^{1}-$ the highest.

Of all selected indicators, those with the highest differentiating power are: All waste generated per GDP unit, Private investment, All recycling waste (\% of total waste), and Resource productivity.

Based on the outcomes for both years under study, three clusters are drawn with different number of countries within each one.

With regard to the data for 2014, Cluster 1 and Cluster 2 include only one country each, Estonia and Bulgaria, respectively, whereas Cluster 3 includes all other 26 countries from EU. This shows that initially the 
countries' starting positions were more or less identical and the transition to circular economy started from relatively similar positions. Two years later (2016), Table 2, which is generated by the cluster analysis, points to a different situation. Once again, three clusters are formed, corresponding to three models of transition to circular economy. Cluster 1 includes Bulgaria and Estonia, Cluster 2 includes 12 countries which, with few exceptions, are the majority of the new Member States, and Cluster 3, comprising 14 countries, covers mainly old Member States and three new Member States that joined EU after 2004.

Table 2 Cluster Membership in 2016

\begin{tabular}{|c|c|c|c|}
\hline $\begin{array}{c}\text { Cluster } \\
\text { Membership }\end{array}$ & Cluster 1 & Cluster 2 & Cluster 3 \\
\hline & $\begin{array}{l}\text { Bulgaria } \\
\text { Estonia }\end{array}$ & $\begin{array}{l}\text { Belgium } \\
\text { Croatia } \\
\text { Slovakia } \\
\text { Finland } \\
\text { Latvia } \\
\text { Lithuania } \\
\text { Sweden } \\
\text { Poland } \\
\text { Hungary } \\
\text { Malta } \\
\text { Portugal } \\
\text { Romania }\end{array}$ & $\begin{array}{l}\text { Czechia } \\
\text { Denmark } \\
\text { Germany } \\
\text { Ireland } \\
\text { Greece } \\
\text { Spain } \\
\text { France } \\
\text { Italy } \\
\text { Cyprus } \\
\text { Luxembourg } \\
\text { Netherlands } \\
\text { Austria } \\
\text { Slovenia } \\
\text { UK }\end{array}$ \\
\hline
\end{tabular}

Source: author's calculations obtained using a cluster analysis in SPSS

The Czech Republic, Cyprus and Slovenia group together with the old Member States. This is an evidence of the existence of meanings in the circular economy indicators that set them apart from the other new Member States and place them closer to the rest of the countries in the cluster. As for Slovenia, its presence in this group is not a surprise. It falls under the EU-15 group also in other analyses.

Examined in the light of circular economy principles and the respective indicators for each of the spheres of Production and consumption, Waste management, Secondary raw materials, and Competitiveness and innovation, it can be argued that the model presented by Cluster 3 is at the most advanced stage of the process of 'closing the loop', whereas that of Cluster 1 lags behind noticeably in ecological transformation. In most indicators, Cluster 2 countries come closer to the Cluster 3 model and the variance between these two clusters is also weaker (Table 3). The highest heterogeneity is observed with All waste generated per GDP unit and Resource productivity + DMC, which could be partially explained with the differences in the countries' production models, their technological levels and degree of economic development.

Table 3 Variance within the clusters by indicator

\begin{tabular}{|l|l|l|l|}
\hline Indicator & $\begin{array}{l}\text { Cluster 1 } \\
\text { Std. } \\
\text { Deviation }\end{array}$ & $\begin{array}{l}\text { Cluster 2 } \\
\text { Std. } \\
\text { Deviation }\end{array}$ & $\begin{array}{l}\text { Cluster 3 } \\
\text { Std. } \\
\text { Deviation }\end{array}$ \\
\hline $\begin{array}{l}\text { All waste generated per GDP unit } \\
2016\end{array}$ & 159,80613 & 36,20606 & 24,50039 \\
\hline $\begin{array}{l}\text { All waste generated per DMC unit } \\
2016\end{array}$ & 14,70782 & 5,81328 & 7,78257 \\
\hline $\begin{array}{l}\text { Recycling rate of municipal waste } \\
2016\end{array}$ & 2,61630 & 14,59417 & 14,18432 \\
\hline $\begin{array}{l}\text { All recycling waste 2016 (\% of total } \\
\text { waste) }\end{array}$ & 1,41421 & 13,96831 & 16,41963 \\
\hline Circular material use rate 2016 & 5,303301 & 4,592088 & 7,748523 \\
\hline Gross value added 2016 &, 00707 &, 31087 &, 45791 \\
\hline Private investment 2016 &, 02121 &, 06403 &, 04977 \\
\hline Jobs 2016 &, 17678 &, 74960 &, 83476 \\
\hline Resource productivity + DMC 2016 & 11,56402 & 25,74183 & 38,36295 \\
\hline
\end{tabular}

Source: author's calculations obtained using a cluster analysis in SPSS 
Compared to the results for 2014, where all countries (except for Bulgaria and Estonia) fall under a single cluster, the outcomes for 2016 show a new configuration of the countries. This could mean that the measures undertaken, the public policy reforms, and the implementation of new national strategies in a number of countries have given results leading to the formation of a group which, based on the selected indicators, becomes clearly distinct from the rest (Cluster 3 ).

Figure 1 gives information about the particular profile of the models in each of the clusters, representing the final cluster centres.
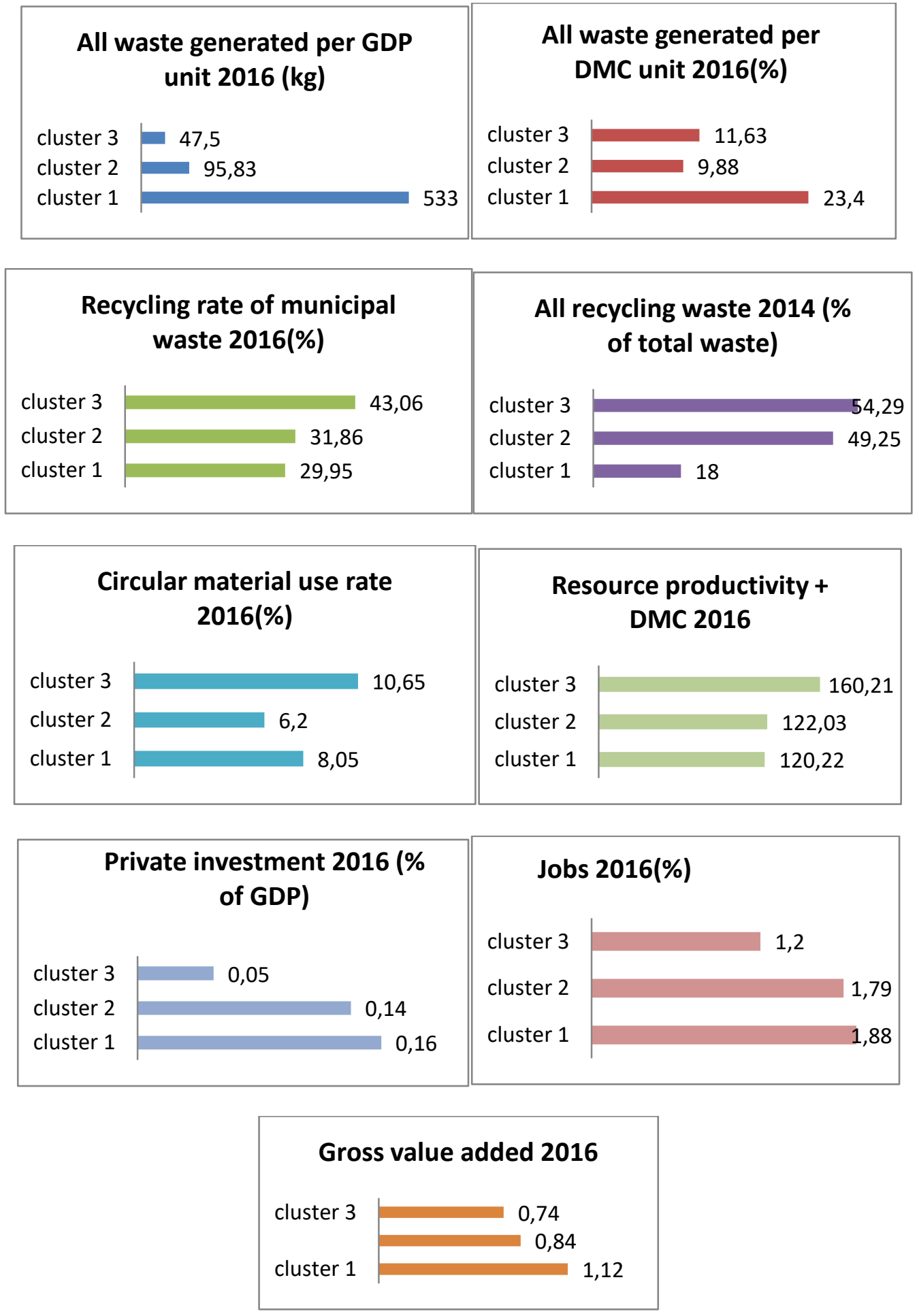

Source: author's calculations obtained using a cluster analysis in SPSS

Fig. 1 Final cluster centres. 
The most serious dissimilarities among the three clusters are outlined in the group of indicators related to production and consumption and resource productivity. With regard to All waste generated per GDP unit, Cluster 2 countries have twice as much generated waste per GDP unit compared to those in the third cluster. This could imply some lagging behind in the process of transition to more efficient use of resources in these countries or that the advantages of circular economy are still being underestimated. In the two countries in Cluster 1 , where this indicator is more than tenfold higher, compared to Cluster 3 they are far behind a successful transition to circular economy model. The reasons can be complex, including the lack of adequate state policy promoting transformation. That also has an impact on the values of the Resource productivity indicator, where the values between the first and the second cluster are almost identical, and in the third the indicator is by $33 \%$ higher.

Apart from showing weaker performance of their indicators in the production and consumption and waste management groups, Bulgaria and Estonia have also made a slower progress from 2014 onwards - a decline in All waste generated per GDP unit from $26 \%$ against $37 \%$ and $78 \%$, respectively, for Cluster 3 and Cluster 2.

Member States use different methods to calculate the levels of recycling, which could explain a part of the differences in the indicator All recycling waste. Often, achieving higher levels of recylcing is limited by the administrative capacity, the absence of investments in the infrastructure of separate collection and recycling, and the insufficient utilisation of economic instruments (such as fees for waste disposal or schemes of the 'pay-as-you-throw' type). The contribution of recycled materials to total materials demand is relatively small. Recycled materials satisfy in average only around $10 \%$ of materials demand in EU, which is unsatisfactory. That could be due to the insufficient profitability of their recycling, the absence of recycling technologies or perhaps some underestimation of the advantages of circular economy by the businesses and the public authoritieis. Secondary raw materials are still only a small part of the production materials used in EU. Their utilisation in the economy faces significant obstacles, such as due to the uncertainty about their composition, the small relative share of the sector and the still prevailing linear model of the economies in most EU countries.

With regard to the indicators from the Competitiveness and innovation group, included in this cluster analysis, the values of Cluster 1 and Cluster 2 are closer and exceed those of the countries under Cluster 3. This could be explained with the efforts carried out by the EU 13 countries (which basically form these two clusters) to create an appropriate infrastructure, to renovate the existing one, and to create jobs in the sectors related to circular economy. These activities require significant investments and extending the scope of businesses, which leads to higher Gross Value Added. The results could also be interpreted as an expression that these economies are catching up in their development and of their desire to make a faster progress.

\section{CONCLUSION}

The study conducted using a set of indicators comprising each of the four main groups - production and consumption, waste management, secondary raw materials, and competitiveness - provides evidence to conclude that there is a considerable heterogeneity across countries, both within the clusters and from country to country. The different progress in the process of transition once again confirms the rationale behind forming separate groups of countries achieving integration with each other at a different speed. Some progress is noticeable towards more circular trends in production, such as in waste generation. There is, however, considerable potential for reducing the differences of performance across Member States and types of materials. Waste generation as a whole indicates a positive development, but still with much room for improvement and dissimilarities both among Member States, and across waste flows. More homogeneous are the clusters with regard to household waste, whereas in terms of general waste the gap is much larger.

The lack of a single indicator for circular economy makes an overall asessment of the progress even more difficult, all the more so as the analysed period (2014-2016) is quite short. It rather serves as a tool for tracing the major trends of transition and for assessing whether the measures adopted and the commitment of all stakeholders were sufficiently effective.

The lesson learned from successful experiences is that the transition towards CE comes from the involvement of all actors of the society and their capacity to link and create suitable collaboration and exchange patterns. The transition towards a circular economy requires fundamental changes to production and consumption systems, going well beyond resource efficiency and recycling waste. Current actions to stimulate and monitor the transition, however, primarily focus on materials, which is not surprising, as the circular economy vision has evolved as a solution to the waste problem, and current policy and business 
tools focus on waste or materials. The shift from product-based to service-based business models is another promising development. Well-tailored governance and finance mechanisms, including innovation incentives, will be required to turn these niche activities into mainstream economic models.

The conclusions reached indicate an existing alignment of some European economies with the linear model of development and delaying the transition to a model of actual circular economy. That calls for adequate measures by the public authorities and for decisive reforms in the eco-fiscal and eco-innovative policies, as well as for stepping up transition by promoting reuse, recycling and extensive adoption of eco-design. Transition towards a CE is underway, therefore, understanding the nature and state of this transition is important for creating effective policies and business strategies.

\section{REFERENCE LIST}

Circular Europe Network (2015) General Guidelines for integrated circular economy strategies at local and regional level, ACR+report, may 2015

European Commission (2008), Sustainable Consumption and Production and Sustainable Industrial Policy Action Plan \{SEC(2008) 2110\} \{SEC(2008) 2111\}, COM(2008) 397 final, Brussels.

European Commission (2015), DIRECTIVE of the European Parliament and Council of the European Union

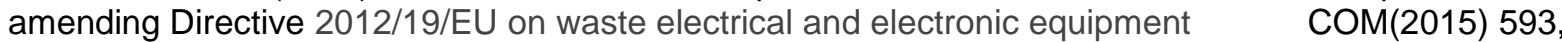

European Commission (2015), DIRECTIVE of the European Parliament and Council of the European Union amending Directive 1999/31/EC on the landfill of waste , COM(2015) 594,

European Commission (2015), DIRECTIVE of the European Parliament and Council of the European Union amending Directive 2008/98/EC on waste COM(2015) 595 and COM(2015)596

European Commission (2015), Closing the loop - An EU action plan for the Circular Economy, $\operatorname{COM}(2015) 614$.

European Commission (2018), COMMUNICATION from the Commission to the European Parliament and Council, the European economic and social committee and the Committee of the regions on a monitoring framework for the circular economy COM/2018/029 final

European Commission (2017), Investing in a smart, innovative and sustainable Industry, A renewed EU Industrial Policy Strategy COM(2017) 479 https:/ / ec.europa.eu /transparency/ regdoc/rep/ 1/2017

European Union(2018), Sustainable development in the European Union, Monitoring Report on progress towards the SDGS in an EU context, 2018 edition, https://ec.europa.eu/eurostat/about/policies/copyright

Ellen MacArthur Foundation (2015) Towards a Circular Economy: Business rationale for an accelerated transition http://www.ellenmacarthurfoundation.org/business/reports

European Parliament and Council of the European Union (2013), Decision No 1386/2013/EU on a General Union Environment Action Programme to 2020 "Living well, within the limits of our planet“.

Ferreira, L., Ad. Figueiredo(2005), Welfare regimes in EU 15 and in the Enlarged Europe: An exploratory analysis, FEP Working papers. N 176, pp.1-35

Haas, W., Krausmann, F., Wiedenhofer, D., Heinz, M., (2015), How Circular is the Global Economy?: An Assessment of Material Flows, Waste Production, and Recycling in the European Union and the World in 2005, in Journal of Industrial Ecology, October 2015, Vol.19(5), pp. 765-777.

Ivanova,V.,(2013) Ivanova, V.(2013) Opportunities for the Green Economy in Bulgaria, Economic Alternatives, Issue 4, 2013, pp.35-45

Ivanova,V., Slavova, I.,(2018) Ecological Transformation in Bulgaria - New Challenges to the Businesses and the Government, European Journal of Economics and Business Studies, ISSN 2411-4073 (online), May-August 2018 Volume 4, Issue 2, p.22-34

ONU(2015) Transformer notre monde : le Programme de developpement durable a l'horizon 2030, Résolution adoptée par 70ème session de l'Assemblée Générale, New York, 18 septembre 2015. Référence Nations unies: A/70/L1, http://www.un.org/ga/search/view doc.asp?symbol=A/RES/70/1\&Lang=F 